\title{
A QUEDA DE TUDO
}

Luísa Modesto é graduada em Letras pela Universidade Presbiteriana Mackenzie e atua como Designer Educacional na editora Pearson Education do Brasil.

E-mail: luisa-modesto@hotmail.com

Hoje tudo cai. As coisas caíram das minhas mãos. A caneta caiu da mesa. As coisas caem e nem ao menos se quebram, entregues à humilhação de estar no chão. Eu observo a queda e, estática, aceito a derrota de tudo. As coisas caem e o barulho não é percebido pelos corpos fórmicos ao redor. Eu da cadeira do escritório conformo a ausência do sentido das coisas em queda, e as vejo míope pelas lentes dos meus óculos sérios. E me coloco neutra a trabalhar. Resigno à queda de tudo. Das folhas (em branco), do copo e de mim. Também das gotas de café que desabam da cafeteira quebrada, estas atingem a superfície quente da máquina e se fazem vapor. Sobre tudo não tenho controle, é vapor. A gravidade é inevitável. E os cacos caem pesados por cima de mim. Os objetos, em sua forma, no chão; as pessoas, disformes, erguidas. O pé da mesa é madeira morta. Mas por vezes vai de encontro aos meus sapatos. Os cadarços um pouco soltos e sujos de chuva. As passadas ao fundo compõem a trilha da cena. E tudo sempre acaba no chão, misturado à poeira do dia. Coisas soltas, perdidas. A queda é livre, in loco. E tudo resiste indiferente. Tudo recolhido nos cantos, e as caixas de canto, vazias.

As coisas atingem o chão. 